\title{
Thiyl Glycosylation of Propargylated Octasilsesquioxane: Synthesis and Lectin-Binding Properties of Densely Glycosylated Clusters on a Cubic Platform
}

\author{
Alberto Marra, ${ }^{[a \mid[\$]}$ Samuele Staderini, ${ }^{[a]}$ Nathalie Berthet, ${ }^{[b]}$ Pascal Dumy, ${ }^{[b] \mid \ddagger]}$ \\ Olivier Renaudet, ${ }^{[b]}$ and Alessandro Dondoni*[a]
}

Keywords: Carbohydrates / Cluster compounds / Glycoconjugates / Click chemistry / Radical reactions / Alkynes / Photochemistry

A new polyhedral oligomeric silsesquioxane (POSS) derivative with a periphery of eight PEGylated chains functionalized with terminal propargyl groups was synthesized starting from commercially available octavinyl-POSS. The photoinduced free-radical coupling of this octapropargyl POSS derivative with various sugar thiols enabled the preparation of globular hexadecavalent glycoclusters. Thus, it appears that according to the alkyne hydrothiolation mechanism, two thiyl radicals were added across each triple bond of the POSS scaffold side-chains. The affinities of some of the densely glycosylated clusters towards certain lectins were measured by the Enzyme-Linked Lectin Assay (ELLA). The binding selectivity of Concanavalin A between the hexadecavalent mannosylated and glucosylated clusters was much higher than the selectivity observed for the corresponding octavalent glycoclusters (ref. ${ }^{[4]}$ ). Moreover, the affinity of the $N$ acetylglucosamine-based cluster towards wheat germ agglutinin (WGA) revealed a remarkable glycoside cluster effect with up to a $9.0 \times 10^{5}$-fold increase in binding compared to monovalent GlcNAc. As a multivalent effect of the same order of magnitude was reported for an octavalent GlcNAc cluster towards the same lectin (ref. ${ }^{[4]}$ ), it is concluded that increasing the number of sugar units around the cubic platform does not lead systematically to an enhancement of binding affinity.

\section{Introduction}

The polyhedral oligomeric silsesquioxane (POSS), actually a rigid silica cube, is mostly known as a nanoscale building block for constructing functional materials. ${ }^{[1]}$ The clustering of biomolecules onto POSS as a chemically and thermally stable platform is also an interesting topic which, however, has scarcely been investigated to date. Nevertheless, quite recently, POSS glycoconjugates (glyco-POSS) have received significant attention due to their rigid globular architecture, in which a precise clustering of eight sugar molecules in space is displayed. Thus, these hybrid inorganic-organic multivalent systems are emerging as interest-

[a] Dipartimento di Chimica, Laboratorio di Chimica Organica, Università di Ferrara,

Via L. Borsari 46, 44100 Ferrara, Italy

Fax: +39-0532-240709

E-mail: adn@unife.it

Homepage: http://web.unife.it/centro/icsi/members/Dondoni/ members.html

[b] Département de Chimie Moléculaire, UMR CNRS 5250, Université Joseph Fourier,

570 Rue de la Chimie, BP 53, 38041 Grenoble cedex 9, France

[\$] Current address: Ecole Nationale Supérieure de Chimie de Montpellier, Equipe "Glycochimie et reconnaissance moléculaire",

8 Rue de l'Ecole Normale, 34000 Montpellier, France

Supporting information for this article is available on the WWW under http://dx.doi.org/10.1002/ejoc.201201453. ing substrates for exploratory biological studies, such as, for example, studies of carbohydrate-lectin interactions. Synthetic routes to glyco-POSS were reported in 2010 by Fessner $^{[2]}$ and Chiara $^{[3]}$ and their co-workers, using the click copper-catalysed cycloaddition of an octaazide silsesquioxane with alkynyl glycosides. A more recent contribution towards this goal was provided by our own group using another click reaction, i.e., the photoinduced free radical coupling of octaene silsesquioxanes (POSS-ene) with sugar thiols to give $S$-linked octavalent POSS-based glycoclusters $^{[4]}$ (Figure 1).

With these glycoclusters, the binding of glyco-POSS to specific lectins was determined for the first time. Notably, in one case, an $\mathrm{IC}_{50}$ value of $3 \mathrm{nM}$ (glycocluster concentration) was observed. Thus, the calculated relative potency per number of sugar units $(r p / n)$ was of the order of $10^{6}$, which reveals a striking glycoside cluster effect. ${ }^{[5]}$ We were stimulated by this exciting result to synthesize further POSS-based glycoclusters and to evaluate their lectin-binding properties. In this paper, we will describe the synthesis of more densely glycosylated POSS derivatives, all featuring 16 sugar fragments (Figure 1), by the addition of sugar thiols to a new POSS-based reagent bearing alkynylated sidearms. ${ }^{[6]}$ The reaction that we planned to use for the ligation was the classical free-radical double hydrothiolation of terminal alkynes, a process that is generally referred to as 

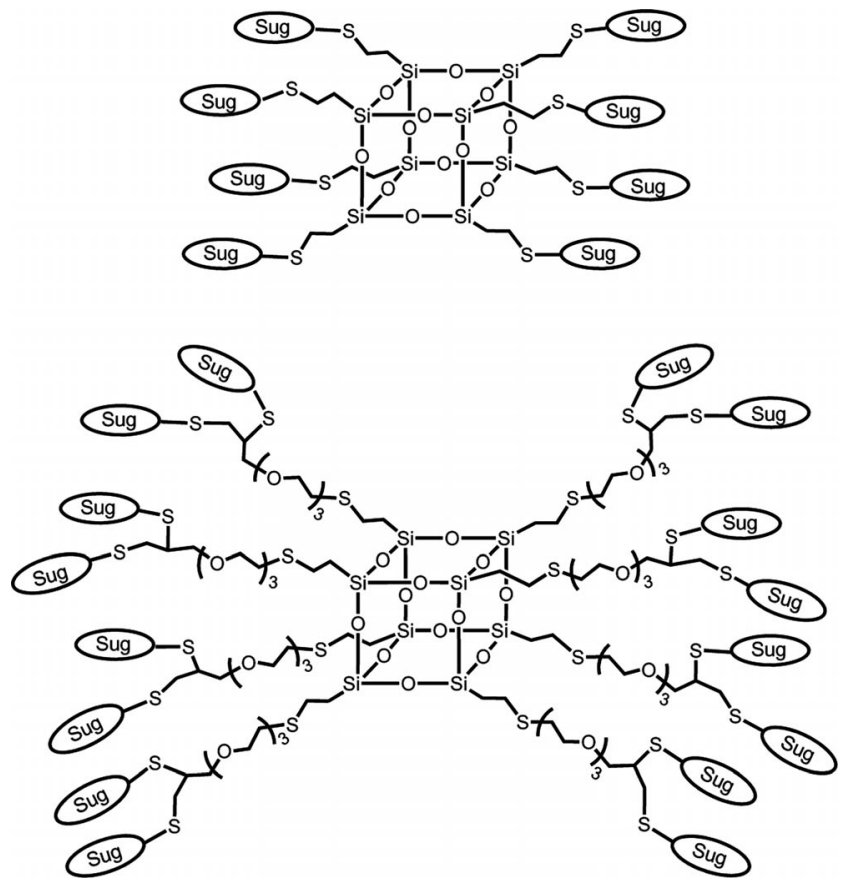

Figure 1. Schematic representation of glyco-POSS prepared (top, ref. ${ }^{[4]}$ ) and targeted in the present work (bottom).

thiol-yne coupling (TYC). It has been well established that TYC can be initiated photochemically, and that it then proceeds by a free-radical chain mechanism that involves a vinyl thioether as a key intermediate ${ }^{[7]}$ (Scheme 1). Notably, TYC leads to the formation of bis-addition products, i.e. dithioethers, by exclusive 1,2-addition of two thiyl radicals across the alkyne triple bond. This reaction, which is a sister reaction to the more commonly used free-radical hydrothiolation of terminal alkenes (thiol-ene coupling, TEC), ${ }^{[8]}$ is emerging as a new metal-free click process, due to its high efficiency, regioselectivity, atom economy, and orthogonality to a great variety of other reactive groups. ${ }^{[9]}$ While the use of TYC has been well documented in polymer and materials synthesis, ${ }^{[7,10]}$ recent reports have described interesting extensions to bioorganic chemistry. ${ }^{[1]} \mathrm{A}$ wide range of applications of TYC in this field can be predicted, owing to

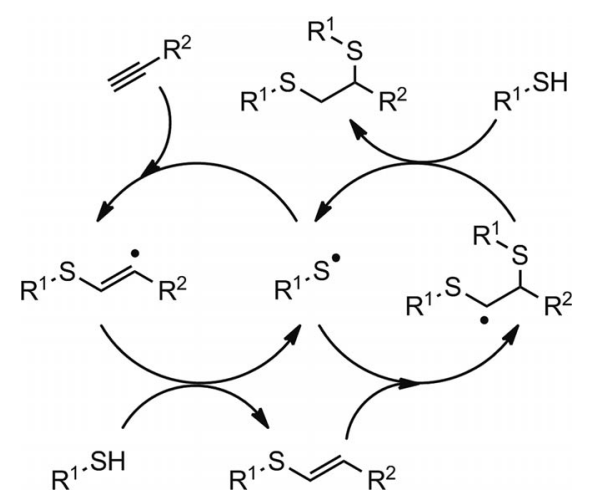

Scheme 1. Mechanism of free-radical thiol-yne coupling. the numerous alkynyl tagged biomolecules that have been prepared for use in Cu-catalysed alkyne-azide cycloadditions (CuAAC) ${ }^{[12]}$

\section{Results and Discussion}

We approached the preparation of octapropargyl silsesquioxane derivative 4 (POSS-yne) by following the synthetic scheme that was recently established for the synthesis of the analogous octaallyl derivative (POSS-ene).${ }^{[4]}$ Accordingly, also POSS-yne 4 was designed to contain PEGylated spacers, as these would avoid steric congestion around the scaffold and induce water solubility and biocompatibility. Briefly, commercially available octavinyl-POSS (1) was transformed as described ${ }^{[4]}$ into octahydroxy functionalized POSS 3 in an almost quantitative yield by TEC with known PEGylated thiol 2 ${ }^{[13]}$ (Scheme 2). Upon treatment of polyalcohol 3 with propargyl bromide and $\mathrm{NaH}$ in DMF as a solvent, it gave the target POSS-yne (i.e., 4) in $84 \%$ yield. The ${ }^{1} \mathrm{H}$ NMR spectrum of this new POSS-based reagent showed a single set of signals at ca. $4.2 \mathrm{ppm}$ (the methylene protons of the propargyl group), consistent with the $T_{8}$ symmetry of the system.<smiles>C=C[Si]12O[Si]3(C=C)O[Si]4(C=C)O[Si](C=C)(O1)O[Si]1(C=C)O[Si](C=C)(O2)O[Si](C=C)(O3)O[Si](C=C)(O4)O1</smiles>

1

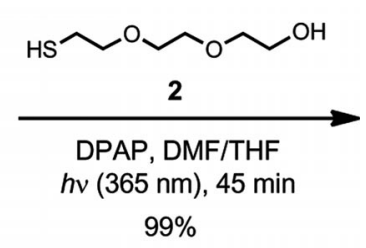

4
Scheme 2. Synthesis of octapropargyl POSS derivative 4.

With substantial amounts of $\mathbf{4}$ in hand, we set out to investigate its photoinduced reactions with sugar thiols. Conditions similar to those used in previous TEC and TYC reactions reported by our group were adopted, i.e., irradiation with a household UVA lamp apparatus $\left(\lambda_{\max }=\right.$ $365 \mathrm{~nm}$ ) in the presence of the photoinitiator 2,2-dimethoxy-2-phenylacetophenone (DPAP). The experiments were carried out in glass vials at room temperature, and no care was taken to exclude air and moisture. In the event, irradiation of a stirred solution of POSS-yne 4, an excess of 2acetamido-2-deoxy-1-thio- $\beta$-D-glucopyranose ${ }^{[14]} \quad \mathbf{5 a}$, and DPAP in DMF (Table 1, Figure 2) gave within $1 \mathrm{~h}$ a reaction mixture that, when analysed by ${ }^{1} \mathrm{H}$ NMR spectroscopy, 
showed no signals in the regions corresponding to the resonances of propargyl and alkenyl protons (4.2 and 5.56.5 ppm, respectively). ${ }^{[15]}$

Table 1. Photoinduced hydrothiolation ${ }^{[\mathrm{a}]}$ of POSS-yne $4^{[\mathrm{b}]}$ by thiols 5a-e.

\begin{tabular}{|c|c|c|c|c|}
\hline Thiol & $\begin{array}{l}\text { Thiol } \\
\text { equiv./yne }\end{array}$ & $\begin{array}{l}\text { DPAP }^{[\mathrm{c}]} \\
\text { equiv./yne }\end{array}$ & Solvent & $\begin{array}{l}\text { Product }^{[\mathrm{d}]} \\
(\text { yield \%) })^{[\mathrm{e}]}\end{array}$ \\
\hline $\mathrm{HO}$ & 4 & 0.3 & DMF & 6a (60) \\
\hline & 8 & 0.3 & $\begin{array}{c}\text { MeOH-DMF } \\
(1: 1)\end{array}$ & 6b (50) \\
\hline & 4 & 0.3 & $\begin{array}{c}\mathrm{MeOH}-\mathrm{DMF} \\
(1: 1)\end{array}$ & 6c $(70)$ \\
\hline & 4 & 0.3 & $\begin{array}{c}\mathrm{MeOH}-\mathrm{DMF} \\
(1: 1)\end{array}$ & 6d (82) \\
\hline & 4 & 0.3 & $\begin{array}{c}\mathrm{MeOH}-\mathrm{DMF} \\
(1: 1)\end{array}$ & 6e (80) \\
\hline
\end{tabular}

[a] Conditions: irradiation at $\lambda_{\max }=365 \mathrm{~nm}$ for $1 \mathrm{~h}$. [b] Scale: 14 $21 \mathrm{mg} \quad(6-9 \mu \mathrm{mol}) . \quad$ [c] 2,2-Dimethoxy-2-phenylacetophenone. [d] See structure in Figure 2. [e] Isolated yields after chromatography.

This indicated an essentially complete conversion of all of the propargyl groups of $\mathbf{4}$, and the absence of any residual vinyl thioether intermediate. Chromatography of the crude reaction mixture gave the target bis adduct glycoPOSS (i.e., 6a; 60\% yield) featuring a hexadecavalent glycocluster installed onto the PEGylated silsesquioxane scaffold by thiother linkages. ${ }^{1} \mathrm{H}$ and ${ }^{13} \mathrm{C}$ NMR spectroscopic data were consistent with the assigned structure. In particular, retention of the anomeric configuration was established by the presence of doublets $\left(J_{1,2}=10.6 \mathrm{~Hz}\right)$ at ca. $4.50 \mathrm{ppm}$ in the ${ }^{1} \mathrm{H}$ NMR spectrum of $\mathbf{6 a}$. No reactions other than the double addition of thiol 5a to the propargyl groups of $\mathbf{4}$ were observed, and most of the excess of $\mathbf{5} \mathbf{a}$ was recovered either unaltered or in the form of the corresponding disulfide.

Encouraged by these results, we decided to investigate the substrate scope of sugar thiols. Hence, we carried out the photoinduced coupling of $\mathbf{4}$ with galactosyl thiol $\mathbf{5 b} \mathbf{b}^{[14]}$ This reaction also gave the corresponding hexadecavalent glycocluster (i.e., 6b) in good isolated yield (Table 1). In this case, however, a large excess of $\mathbf{5 b}$ (8 equiv. per alkyne group) was used in order to complete the double hydrothiolation of all eight of the propargyl groups of 4 . A reaction in which 4 equiv. of $\mathbf{5 b}$ per alkyne group of $\mathbf{4}$ was used did not reach completion, as shown by ${ }^{1} \mathrm{H}$ NMR spectroscopy. This decrease in reactivity may be ascribed to shielding of
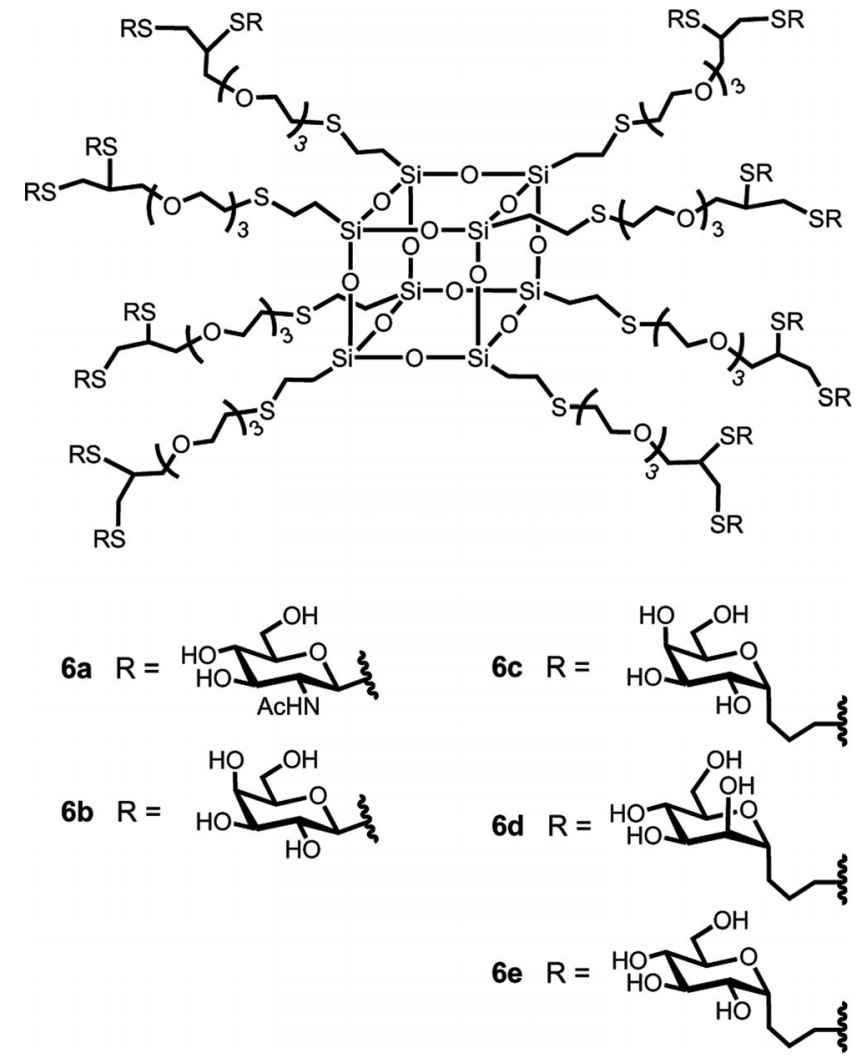

Figure 2. POSS-glyco 6a-e prepared from PEGylated POSS-yne 4 and sugar thiols $\mathbf{5 a - e .}$

the free sulfhydryl group of $\mathbf{5} \mathbf{b}$ by the axial hydroxy group at C-4 of the sugar moiety. Therefore, we decided to use a less encumbered thiol in which the sulfhydryl group was separated from the sugar moiety by an alkyl spacer. The photoinduced reaction of thiopropyl $C$-galactoside $\mathbf{5 c}$ with 4 was essentially complete using the usual excess of thiol (4 equiv. per alkynyl group), and the target bis adduct (i.e., 6c) was formed in good yield (Table 1). Successful results were also obtained by coupling 4 with thiopropyl $C$-mannoside $\mathbf{5}^{[4]}$ and thiopropyl $C$-glucoside $5 \mathbf{e}^{[4]}$ to give the corresponding POSS-based glycoclusters (i.e., 6d and 6e) in high yields (Table 1).

The binding properties of the hexadecavalent glycoclusters $\mathbf{6 a}, \mathbf{6 d}$, and $\mathbf{6 e}$ towards certain lectins were determined with an Enzyme-Linked Lectin Assay (ELLA) to assess whether the higher number of sugar moieties would improve the affinity found for the octavalent POSS-based glycoclusters reported in our previous paper. ${ }^{[4]}$ However, given the recent finding by Sundberg, Chiara, and co-workers ${ }^{[16]}$ on the disassembling of triazole-linked glycoconjugates with a POSS core in aqueous media, we wondered whether this would also occur for our compounds under the ELLA test conditions. To investigate this, a solution of $\mathbf{6 d}$ in deuterated $0.01 \mathrm{~m}$ phosphate-buffered saline (PBS) at $\mathrm{pH} 7.4$ was heated at $37^{\circ} \mathrm{C}$ for $16 \mathrm{~h}$ and monitored at various intervals by ${ }^{1} \mathrm{H}$ NMR spectroscopy. To our delight, the NMR spectra remained almost unchanged (see Figure S2), thus showing the stability of the POSS-based glycoclusters under 
the conditions of the ELLA tests ( $\mathrm{pH} 7.4,37^{\circ} \mathrm{C}, 2 \mathrm{~h}$ ). Mannosylated and glucosylated clusters $\mathbf{6 d}$ and $\mathbf{6 e}$ were submitted to the ELLA experiments using Concanavalin A (ConA), a lectin from Canavalia ensiformis, which is specific for $\alpha$-D-mannopyranosides and $\alpha$-D-glucopyranosides. Compound 6d showed good inhibition of the binding of horseradish-peroxidase-labelled ConA (ConA-HRP) to an $\alpha$-D-mannose-polyacrylamide conjugate ( $\alpha$-D-Man-PAA) with an $\mathrm{IC}_{50}$ of $0.179 \mu \mathrm{M}$, which corresponds to a relative potency ( $r p$ ) of 2564 with respect to methyl $\alpha$-D-mannopyranoside, which was used as a monovalent reference (Table 2, Figure $\mathrm{S} 1$ ). This $r p$ value was significantly higher (53 times) than that found for the corresponding octavalent glycoclus$\operatorname{ter}^{[4]}(r p=48.2)$. When reported relative to the number of sugar units $(r p / n=160)$, the inhibition enhancement was 27-fold, indicating a moderate glycoside cluster effect (Table 2). However, the experimental data cannot establish whether this effect was mainly due to the higher sugar valency (i.e., 16 vs. 8), or to the presence of a PEGylated linker between the mannose moieties and the platform. Moreover, it has to be mentioned that only a few studies have reported higher binding enhancements for ConA. ${ }^{[17-19]}$

Table 2. ELLA data for the inhibition of the binding of the lectin ConA-HRP to $\alpha$-D-Man-PAA by glycoclusters $6 \mathbf{d}$ and $\mathbf{6 e}$, and the inhibition of the binding of the lectin WGA-HRP to D-GlcNAcPAA by glycocluster $\mathbf{6 a}$. ${ }^{[a]}$

\begin{tabular}{lllll}
\hline & $n^{[\mathrm{b}]}$ & $\mathrm{IC}_{50}[\mu \mathrm{M}]$ & $r p^{[\mathrm{c}]}$ & $r p / n^{[\mathrm{d}]}$ \\
\hline Me $\alpha$-D-Man & 1 & $459 \pm 26$ & 1 & 1 \\
6d & 16 & $0.179 \pm 0.011$ & 2564 & 160 \\
Me $\alpha$-D-Glc & 1 & $2108 \pm 75$ & 1 & 1 \\
6e & 16 & $4.4 \pm 0.6$ & 479 & 30 \\
D-GlcNAc & 1 & $28800 \pm 2200$ & 1 & 1 \\
6a & 16 & $0.002 \pm 5^{-5}$ & $14.4 \times 10^{6}$ & $9.0 \times 10^{5}$ \\
\hline
\end{tabular}

[a] Each experiment was performed in triplicate. [b] Number of sugar units. [c] rp: relative potency $=\mathrm{IC}_{50}$ (monosaccharide) $/ \mathrm{IC}_{50^{-}}$ (glycocluster). [d] $r p / n$ : relative potency/number of sugar units.

Similarly, hexadecavalent glucosylated cluster $6 \mathbf{6}$ showed stronger inhibition $\left(\mathrm{IC}_{50}=4.4 \mu \mathrm{M} ; r p=479\right)$ than its octavalent counterpart ${ }^{[4]}\left(\mathrm{IC}_{50}=40.4 \mu \mathrm{M} ; r p=35.2\right)$, although the enhancement of inhibition (13-fold) was lower than that observed in the D-mannose series (Table 2, Figure S1). It is worth noting that the selectivity of ConA between hexadecavalent clusters $\mathbf{6 d}$ and $\mathbf{6 e}\left[\mathrm{IC}_{50}(\mathbf{6 e}) / \mathrm{IC}_{50}(\mathbf{6 d})=24.6\right]$ was much higher than the selectivity observed for the corresponding octavalent glycoclusters $\left(\mathrm{IC}_{50}\right.$ ratio $\left.=5.9\right)$. This finding suggests that the spatial orientation of sugars is more favourable in $\mathbf{6 d}$.

In a previous paper, ${ }^{[4]}$ we reported the unprecedented inhibition of wheat germ agglutinin (WGA), a lectin from Triticum vulgaris that is specific for $N$-acetyl-D-glucosamine (GlcNAc), by a POSS-based octavalent GlcNAc cluster $\left(\mathrm{IC}_{50}=3 \mathrm{nM} ; r p=9.3 \times 10^{6} ; r p / n=10^{6}\right)$. Hexadecavalent $\mathrm{N}$-acetyl-D-glucosamine cluster $\mathbf{6 a}$ also showed remarkably strong inhibition properties towards WGA when submitted to similar ELLA experiments $\left(\mathrm{IC}_{50}=2 \mathrm{nM}\right.$ ), although the $r p\left(14.4 \times 10^{6}\right)$ and $r p / n\left(9.0 \times 10^{5}\right)$ values were only slightly higher or even lower, respectively, than those found for the corresponding octavalent cluster (Table 2). This observation indicated that increasing the number of sugar units around the cubic platform does not lead systematically to an affinity enhancement, in particular when the affinity of the multivalent ligand is in the nanomolar range. ${ }^{[18,20,21]}$

\section{Conclusions}

We have succeeded in preparing five densely glycosylated silsesquioxanes by TYC, all featuring 16 carbohydrate fragments attached to the POSS scaffold by thioether linkages. The pure compounds were isolated in very good yields, although some material was lost upon chromatography on Sephadex LH-20. The compounds are $S$ - and $C$-glycosides, and are therefore expected to be endowed with enhanced chemical stability and enzymatic resistance. Finally, it must also be pointed out that all of the isolated products were mixtures of diastereoisomers, very likely in 1:1 ratios, due to the lack of stereoselectivity of the thiyl radical addition to the vinyl thioether intermediate. No attempts were made to separate individual stereoisomers, as this matter was beyond the scope of the present work. Therefore, it cannot ruled out that separation or stereoselective synthesis of pure stereoisomers could allow the identification of even stronger and more selective lectin ligands.

\section{Experimental Section}

General Methods: Flash column chromatography was performed on silica gel $60(40-63 \mathrm{~mm}) .{ }^{1} \mathrm{H}(300$ and $400 \mathrm{MHz})$ and ${ }^{13} \mathrm{C}(75$ and $100 \mathrm{MHz}$ ) NMR spectra were recorded from $\mathrm{D}_{2} \mathrm{O}$ solutions at room temperature unless otherwise specified. Peak assignments were aided by ${ }^{1} \mathrm{H}-{ }^{1} \mathrm{H}$ COSY and gradient-HMQC experiments. In the ${ }^{1} \mathrm{H}$ NMR spectra reported below, the $n$ and $m$ values quoted in geminal or vicinal proton-proton coupling constants $J_{n, m}$ refer to the numbers of the corresponding sugar protons.

Commercially available octavinyl-POSS (1) and photoinitiator 2,2dimethoxy-2-phenylacetophenone (DPAP) were used without further purification. Horseradish-peroxidase-labelled Concanavalin A (ConA-HRP) and Triticum vulgaris lectin (wheat germ agglutinin; WGA-HRP), Bovine Serum Albumin (BSA), and SIGMAFAST $O$-phenylenediamine dihydrochloride (OPD) were purchased from Sigma-Aldrich. The $\alpha$-D-mannose-polyacrylamide ( $\alpha$-D-Man-PAA) and 2-acetamido-2-deoxy-D-glucose-polyacrylamide (D-GlcNAcPAA) were obtained from Lectinity Holding, Inc., Moscow.

The thiol-yne coupling was carried out in a glass vial (diameter: $1 \mathrm{~cm}$; wall thickness: $0.65 \mathrm{~mm}$ ), sealed with a natural rubber septum, located $2.5 \mathrm{~cm}$ away from a household UVA lamp apparatus equipped with four $15 \mathrm{~W}$ tubes $(1.5 \times 27 \mathrm{~cm}$ each $)$.

Octapropargyl-Substituted Silsesquioxane (4): $\mathrm{NaH}$ (64 mg, $1.60 \mathrm{mmol}$, of a $60 \%$ dispersion in oil) and then freshly distilled propargyl bromide $(120 \mu \mathrm{L}, 1.60 \mathrm{mmol})$ were added to a stirred, cooled $\left(0^{\circ} \mathrm{C}\right)$ solution of $3(98 \mathrm{mg}, 50.0 \mu \mathrm{mol})$ in anhydrous DMF $(4 \mathrm{~mL})$. The mixture was stirred at $0{ }^{\circ} \mathrm{C}$ for $3 \mathrm{~h}$, then diluted with phosphate buffer at pH 7 (1 $\mathrm{M} ; 2 \mathrm{~mL})$, warmed to r.t., diluted with $\mathrm{H}_{2} \mathrm{O}(30 \mathrm{~mL})$, and extracted with EtOAc $(3 \times 50 \mathrm{~mL})$. The combined organic extracts were dried $\left(\mathrm{Na}_{2} \mathrm{SO}_{4}\right)$ and concentrated. The residue was eluted from a column of Sephadex LH-20 with $\mathrm{MeOH}$ to give 4 (95 mg, $84 \%$ ) as a syrup. ${ }^{1} \mathrm{H}$ NMR (400 MHz, $\left.\mathrm{CDCl}_{3}\right): \delta$ 
$=4.20\left(\mathrm{~s}, 16 \mathrm{H}, 8 \mathrm{CH}_{2} \mathrm{C} \equiv \mathrm{CH}\right), 3.76-3.57\left(\mathrm{~m}, 80 \mathrm{H}, 40 \mathrm{CH}_{2} \mathrm{O}\right)$, 2.78-2.56 (m, $32 \mathrm{H}, 16 \mathrm{CH}_{2} \mathrm{~S}$ ), 2.45 (br. s, $\left.8 \mathrm{H}, 8 \mathrm{C} \equiv \mathrm{CH}\right) 1.12$ 0.94 (m, $\left.16 \mathrm{H}, 8 \mathrm{CH}_{2} \mathrm{Si}\right) \mathrm{ppm} .{ }^{13} \mathrm{C} \mathrm{NMR}\left(100 \mathrm{MHz}, \mathrm{CDCl}_{3}\right): \delta=$ $79.7(\mathrm{CH}), 74.7(\mathrm{CH}), 70.5\left(\mathrm{CH}_{2}\right), 70.3\left(\mathrm{CH}_{2}\right), 69.1\left(\mathrm{CH}_{2}\right), 58.4$ $\left(\mathrm{CH}_{2}\right), 31.3\left(\mathrm{CH}_{2}\right), 26.7\left(\mathrm{CH}_{2}\right), 14.2\left(\mathrm{CH}_{2}\right)$ ppm. MS (MALDITOF): calcd. for $\mathrm{C}_{88} \mathrm{H}_{152} \mathrm{NaO}_{36} \mathrm{~S}_{8} \mathrm{Si}_{8}[\mathrm{M}+\mathrm{Na}]^{+}$2287.59; found 2287.60 .

4,8-Anhydro-1,2,3-trideoxy-1-thio-D-glycero-L-gluco-nonitol (5c): A solution of allyl 2,3,4,6-tetra- $O$-acetyl- $C$ - $\alpha$-D-galactopyranoside (186 mg, $0.50 \mathrm{mmol})$, thioacetic acid $(53 \mu \mathrm{L}, 0.75 \mathrm{mmol})$, and DPAP $(19 \mathrm{mg}, 75 \mu \mathrm{mol})$ in $\mathrm{MeOH}(0.5 \mathrm{~mL})$ was irradiated at r.t. for $1 \mathrm{~h}$ with magnetic stirring, and then the mixture was concentrated. The residue was eluted from a column of silica gel with 2:1 cyclohexane/EtOAc to give 1,5,6,7,9-penta- $O$-acetyl-4,8-anhydro1,2,3-trideoxy-1-thio-D-glycero-L-gluco-nonitol $(190 \mathrm{mg}, 85 \%)$ as a syrup. $[\alpha]_{\mathrm{D}}=+76.6\left(c=0.8, \mathrm{CHCl}_{3}\right) .{ }^{1} \mathrm{H} \mathrm{NMR}\left(300 \mathrm{MHz}, \mathrm{CDCl}_{3}\right)$ : $\delta=5.40\left(\mathrm{dd}, J_{6,7}=3.0, J_{7,8}=2.0 \mathrm{~Hz}, 1 \mathrm{H}, 7-\mathrm{H}\right), 5.24\left(\mathrm{dd}, J_{4,5}=\right.$ 5.0, $\left.J_{5,6}=9.8 \mathrm{~Hz}, 1 \mathrm{H}, 5-\mathrm{H}\right), 5.17(\mathrm{dd}, 1 \mathrm{H}, 6-\mathrm{H}), 4.24-4.15$ and 4.12-3.98 (2 m, 4 H, 4-H, 8-H, 2 9-H), 2.98-2.82 (m, 2 H, 2 1-H), 2.34 (s, $3 \mathrm{H}, \mathrm{SAc}), 2.12,2.08,2.05$, and 2.02 (4 s, $12 \mathrm{H}, 4 \mathrm{Ac}), 1.82$ 1.44 (m, 4 H, 2 2-H, 3-H) ppm. ${ }^{13} \mathrm{C}$ NMR $\left(75 \mathrm{MHz}, \mathrm{CDCl}_{3}\right): \delta=$ $195.5(\mathrm{C}), 170.6(\mathrm{C}), 170.1(\mathrm{C}), 170.0(\mathrm{C}), 169.8(\mathrm{C}), 71.6(\mathrm{CH})$, $68.3(\mathrm{CH}), 68.1(\mathrm{CH}), 67.9(\mathrm{CH}), 67.6(\mathrm{CH}), 61.5\left(\mathrm{CH}_{2}\right), 30.6$ $\left(\mathrm{CH}_{3}\right), 28.6\left(\mathrm{CH}_{2}\right), 25.5\left(\mathrm{CH}_{2}\right), 24.7\left(\mathrm{CH}_{2}\right), 20.8\left(\mathrm{CH}_{3}\right), 20.7\left(\mathrm{CH}_{3}\right)$ ppm. HRMS (ESI/Q-TOF): calcd. for $\mathrm{C}_{19} \mathrm{H}_{28} \mathrm{NaO}_{10} \mathrm{~S}[\mathrm{M}+\mathrm{Na}]^{+}$ 471.1301; found 471.1315.

$\mathrm{NaOMe}(0.2 \mathrm{M}$ solution in $\mathrm{MeOH}$, prepared from $\mathrm{Na}$ and $\mathrm{MeOH}$ immediately before use; $1 \mathrm{~mL}$ ) was added to a solution of the thioacetate $(161 \mathrm{mg}, 0.36 \mathrm{mmol})$ in $\mathrm{MeOH}(3 \mathrm{~mL})$. The solution was kept at r.t. for $2 \mathrm{~h}$ under a nitrogen atmosphere, then it was neutralized with Amberlite IR-120 resin $\left(\mathrm{H}^{+}\right.$form, activated and washed with $\mathrm{H}_{2} \mathrm{O}$ and $\mathrm{MeOH}$ immediately before use), and filtered through a sinteredglass filter. The resin was washed with $\mathrm{MeOH}$, and the solution was concentrated. The residue was eluted from a C-18 silica gel cartridge with $1: 1 \mathrm{H}_{2} \mathrm{O} / \mathrm{MeOH}$ to give $\mathbf{5 c}(60 \mathrm{mg}$, $70 \%)$ as a syrup. $[a]_{\mathrm{D}}=+91.0\left(c=1.0, \mathrm{H}_{2} \mathrm{O}\right) .{ }^{1} \mathrm{H}$ NMR $(300 \mathrm{MHz})$ : $\delta=3.94-3.27$ and 3.66-3.52 (2 m, 7 H, 5-H, 6-H, 7-H, 8-H, 2 9H), 2.52-2.38 (m, 2 H, 2 1-H), 1.76-1.43 (m, 4 H, 2 2-H, 2 3-H) ppm. ${ }^{13} \mathrm{C}$ NMR (75 MHz): $\delta=75.4(\mathrm{CH}), 71.8(\mathrm{CH}), 69.9(\mathrm{CH})$, $69.3(\mathrm{CH}), 68.5(\mathrm{CH}), 61.3\left(\mathrm{CH}_{2}\right), 37.9\left(\mathrm{CH}_{2}\right), 24.7\left(\mathrm{CH}_{2}\right), 22.4$ $\left(\mathrm{CH}_{2}\right)$ ppm. HRMS (ESI/Q-TOF): calcd. for $\mathrm{C}_{9} \mathrm{H}_{18} \mathrm{NaO}_{5} \mathrm{~S}[\mathrm{M}+$ $\mathrm{Na}]^{+}$261.0773; found 261.0780.

Glycoconjugate 6a: A solution of $\mathbf{4}(15 \mathrm{mg}, 6.6 \mu \mathrm{mol})$, thiol 5a $(50 \mathrm{mg}, 211.7 \mu \mathrm{mol})$, and DPAP $(4.1 \mathrm{mg}, 15.9 \mu \mathrm{mol})$ in DMF $(300 \mu \mathrm{L})$ was irradiated at r.t. for $1 \mathrm{~h}$ with magnetic stirring, and then the mixture was concentrated. The residue was eluted from a column of Sephadex LH-20 with 1:1 $\mathrm{MeOH} / \mathrm{H}_{2} \mathrm{O}$ to give $6 \mathbf{6}(24 \mathrm{mg}$, $60 \%$ ) as a syrup. ${ }^{1} \mathrm{H}$ NMR $(400 \mathrm{MHz})$ selected data: $\delta=4.57$ and $4.51\left(2 \mathrm{~d}, J_{1,2}=10.6 \mathrm{~Hz}, 16 \mathrm{H}, 161-\mathrm{H}\right), 3.79\left(\mathrm{br} . \mathrm{d}, J_{6 \mathrm{a}, 6 \mathrm{~b}}=\right.$ $12.0 \mathrm{~Hz}, 16 \mathrm{H}, 16$ 6a-H), 3.02-2.56 (m, $\left.64 \mathrm{H}, 8 \mathrm{CHS}, 24 \mathrm{CH}_{2} \mathrm{~S}\right)$, 1.93 (s, $48 \mathrm{H}, 16 \mathrm{Ac}), 1.05-0.90$ (m, $\left.16 \mathrm{H}, 8 \mathrm{CH}_{2} \mathrm{Si}\right) \mathrm{ppm} .{ }^{13} \mathrm{C} \mathrm{NMR}$ $(100 \mathrm{MHz}): \delta=174.0(\mathrm{C}), 85.5(\mathrm{CH}), 83.8(\mathrm{CH}), 79.9(\mathrm{CH}), 75.0$ $(\mathrm{CH}), 69.7\left(\mathrm{CH}_{2}\right), 60.9\left(\mathrm{CH}_{2}\right), 54.7(\mathrm{CH}), 30.6\left(\mathrm{CH}_{2}\right), 22.2\left(\mathrm{CH}_{3}\right)$, $14.2\left(\mathrm{CH}_{2}\right)$ ppm. $\mathrm{C}_{216} \mathrm{H}_{392} \mathrm{~N}_{16} \mathrm{O}_{116} \mathrm{~S}_{24} \mathrm{Si}_{8} \cdot 8 \mathrm{H}_{2} \mathrm{O}$ (6063.64): calcd. $\mathrm{C}$ 41.79, H 6.62, N 3.61, S 12.40; found C 41.52, H 6.50, N 3.67, S 12.77 .

Glycoconjugate 6b: A solution of 4 (14 mg, $6.2 \mu \mathrm{mol})$, galactosyl thiol $\mathbf{5 b}(77 \mathrm{mg}, 395.2 \mu \mathrm{mol})$, and DPAP $(3.8 \mathrm{mg}, 14.8 \mu \mathrm{mol})$ in $1: 1$ $\mathrm{MeOH}-\mathrm{DMF}(300 \mu \mathrm{L})$ was irradiated at r.t. for $1 \mathrm{~h}$ with magnetic stirring, and then the mixture was concentrated. The residue was eluted from a column of Sephadex $\mathrm{LH}-20$ with $1: 1 \mathrm{MeOH} / \mathrm{H}_{2} \mathrm{O}$ to give $6 \mathbf{b}(16.7 \mathrm{mg}, 50 \%)$ as a syrup. ${ }^{1} \mathrm{H}$ NMR (400 MHz) selected data: $\delta=4.45,4.44,4.38$, and $4.34\left(4 \mathrm{~d}, J_{1,2}=9.5 \mathrm{~Hz}, 16 \mathrm{H}, 161-\right.$ $\mathrm{H}), 3.04-2.84$ and $2.68-2.50\left(2 \mathrm{~m}, 64 \mathrm{H}, 8 \mathrm{CHS}, 24 \mathrm{CH}_{2} \mathrm{~S}\right), 1.02-$ 0.85 (m, $\left.16 \mathrm{H}, 8 \mathrm{CH}_{2} \mathrm{Si}\right) \mathrm{ppm} .{ }^{13} \mathrm{C}$ NMR $(100 \mathrm{MHz})$ selected data: $\delta=87.1(\mathrm{CH}), 85.8(\mathrm{CH}), 85.2(\mathrm{CH}), 78.9(\mathrm{CH}), 73.8(\mathrm{CH}), 71.7$ $\left(\mathrm{CH}_{2}\right), 69.8\left(\mathrm{CH}_{2}\right), 69.6\left(\mathrm{CH}_{2}\right), 68.7(\mathrm{CH}), 61.0\left(\mathrm{CH}_{2}\right)$ ppm. $\mathrm{C}_{184} \mathrm{H}_{344} \mathrm{O}_{116} \mathrm{~S}_{24} \mathrm{Si}_{8} \cdot 8 \mathrm{H}_{2} \mathrm{O}$ (5406.80): calcd. C 39.81, H 6.54, S 13.86; found C 39.46, H 6.24, S 13.33 .

Glycoconjugate 6c: A solution of thiol 5c (71 mg, $296.4 \mu \mathrm{mol})$ and DPAP $(5.7 \mathrm{mg}, 22.2 \mu \mathrm{mol})$ in $\mathrm{MeOH}(200 \mu \mathrm{L})$ was added to a solution of $4(21 \mathrm{mg}, 9.3 \mu \mathrm{mol})$ in DMF $(200 \mu \mathrm{L})$. The solution was irradiated at r.t. for $1 \mathrm{~h}$ with magnetic stirring, and then it was concentrated. The residue was eluted from a column of Sephadex LH-20 with $1: 1 \mathrm{MeOH} / \mathrm{H}_{2} \mathrm{O}$ to give $6 \mathbf{c}(39.5 \mathrm{mg}, 70 \%)$ as a syrup. ${ }^{1} \mathrm{H}$ NMR (400 MHz) selected data: $\delta=2.80-2.48$ (m, $88 \mathrm{H}, 8 \mathrm{CHS}$, $\left.40 \mathrm{CH}_{2} \mathrm{~S}\right), 1.70-1.45\left(\mathrm{~m}, 64 \mathrm{H}, 16 \mathrm{CH}_{2} \mathrm{CH}_{2}\right), 1.02-0.82(\mathrm{~m}, 16 \mathrm{H}$, $\left.8 \mathrm{CH}_{2} \mathrm{Si}\right) \mathrm{ppm} .{ }^{13} \mathrm{C}$ NMR $(100 \mathrm{MHz})$ selected data: $\delta=75.0(\mathrm{CH})$, $71.5(\mathrm{CH}), 69.8\left(\mathrm{CH}_{2}\right), 68.9(\mathrm{CH}), 68.2(\mathrm{CH}), 61.0\left(\mathrm{CH}_{2}\right), 30.6$

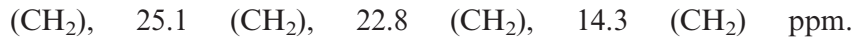
$\mathrm{C}_{232} \mathrm{H}_{440} \mathrm{O}_{116} \mathrm{~S}_{24} \mathrm{Si}_{8} \cdot 8 \mathrm{H}_{2} \mathrm{O}$ (6080.09): calcd. C 44.77, H 7.38, S 12.36; found C 44.70, H 6.81, S 12.42 .

Glycoconjugate 6d: Octapropargyl POSS 4 (21 mg, $9.3 \mu \mathrm{mol})$ was treated with thiol $\mathbf{5 d}(71 \mathrm{mg}, 296.4 \mathrm{mmol})$ as described for the preparation of $\mathbf{6 c}$ to give, after chromatography on Sephadex LH-20 $\left(1: 1 \mathrm{MeOH} / \mathrm{H}_{2} \mathrm{O}\right)$, 6d $(46 \mathrm{mg}, 82 \%)$ as a syrup. ${ }^{1} \mathrm{H}$ NMR (400 MHz) selected data: $\delta=3.00-2.51\left(\mathrm{~m}, 88 \mathrm{H}, 8 \mathrm{CHS}, 40 \mathrm{CH}_{2} \mathrm{~S}\right)$, 1.84-1.43 (m, $\left.64 \mathrm{H}, 16 \mathrm{CH}_{2} \mathrm{CH}_{2}\right), 1.07-0.91\left(\mathrm{~m}, 16 \mathrm{H}, 8 \mathrm{CH}_{2} \mathrm{Si}\right)$ ppm. ${ }^{13} \mathrm{C}$ NMR $(75 \mathrm{MHz}): \delta=78.1(\mathrm{CH}), 73.8(\mathrm{CH}), 72.6\left(\mathrm{CH}_{2}\right)$, $71.7(\mathrm{CH}), 71.1(\mathrm{CH}), 70.2\left(\mathrm{CH}_{2}\right), 67.4(\mathrm{CH}), 61.4\left(\mathrm{CH}_{2}\right), 45.1$ $(\mathrm{CH}), 34.3\left(\mathrm{CH}_{2}\right), 32.2\left(\mathrm{CH}_{2}\right), 30.6\left(\mathrm{CH}_{2}\right), 26.9\left(\mathrm{CH}_{2}\right), 25.9\left(\mathrm{CH}_{2}\right)$, $22.8\left(\mathrm{CH}_{2}\right), 14.2\left(\mathrm{CH}_{2}\right)$ ppm. $\mathrm{C}_{232} \mathrm{H}_{440} \mathrm{O}_{116} \mathrm{~S}_{24} \mathrm{Si}_{8} \cdot 8 \mathrm{H}_{2} \mathrm{O}(6080.09)$ : calcd. C 44.77, H 7.38, S 12.36; found C 45.11, H 7.41, S 12.77 .

Glycoconjugate 6e: Octapropargyl POSS 4 (21 mg, $9.3 \mu \mathrm{mol})$ was treated with thiol 5e $(71 \mathrm{mg}, 296.4 \mathrm{mmol})$ as described for the preparation of $\mathbf{6 c}$ to give, after chromatography on Sephadex LH-20 $\left(1: 1 \mathrm{MeOH} / \mathrm{H}_{2} \mathrm{O}\right)$, 6e $(45 \mathrm{mg}, 80 \%)$ as a syrup. ${ }^{1} \mathrm{H}$ NMR (400 MHz) selected data: $\delta=3.04-2.46\left(\mathrm{~m}, 88 \mathrm{H}, 8 \mathrm{CHS}, 40 \mathrm{CH}_{2} \mathrm{~S}\right)$, $1.77-1.40\left(\mathrm{~m}, 64 \mathrm{H}, 16 \mathrm{CH}_{2} \mathrm{CH}_{2}\right), 1.10-0.89\left(\mathrm{~m}, 16 \mathrm{H}, 8 \mathrm{CH}_{2} \mathrm{Si}\right)$ ppm. ${ }^{13} \mathrm{C}$ NMR $(75 \mathrm{MHz}): \delta=75.7(\mathrm{CH}), 73.6(\mathrm{CH}), 72.6(\mathrm{CH})$, $71.4(\mathrm{CH}), 70.4(\mathrm{CH}), 70.2\left(\mathrm{CH}_{2}\right), 61.3\left(\mathrm{CH}_{2}\right), 45.1(\mathrm{CH}), 34.3$ $\left(\mathrm{CH}_{2}\right), 32.3\left(\mathrm{CH}_{2}\right), 30.7\left(\mathrm{CH}_{2}\right), 26.3\left(\mathrm{CH}_{2}\right), 25.6\left(\mathrm{CH}_{2}\right), 23.2\left(\mathrm{CH}_{2}\right)$, $14.1\left(\mathrm{CH}_{2}\right)$ ppm. $\mathrm{C}_{232} \mathrm{H}_{440} \mathrm{O}_{116} \mathrm{~S}_{24} \mathrm{Si}_{8} \cdot 8 \mathrm{H}_{2} \mathrm{O}$ (6080.09): calcd. $\mathrm{C}$ 44.77, H 7.38, S 12.36; found C 44.56, H 7.39, S 12.62 .

Enzyme-Linked Lectin Assay (ELLA): Microtitre Nunc-Immuno plates (96-well; Maxi-Sorp) were coated with $\alpha$-D-Man-PAA or DGlcNAc-PAA $[100 \mu \mathrm{L}$ per well, diluted from a stock solution of $5 \mu \mathrm{g} \mathrm{mL}^{-1}$ in $0.01 \mathrm{M}$ phosphate-buffered saline (PBS) at $\mathrm{pH} 7.4$ (containing $0.1 \mathrm{mM} \mathrm{Ca}^{2+}$ and $0.1 \mathrm{mM} \mathrm{Mn}^{2+}$ for the ConA assay)] for $1 \mathrm{~h}$ at $37^{\circ} \mathrm{C}$. The wells were then washed with T-PBS $[3 \times$ $100 \mu \mathrm{L}$ per well, PBS containing $0.05 \%$ (v/v) Tween 20]. The washing procedure was repeated after each incubation. The wells were then blocked with BSA in PBS $\left(3 \% \mathrm{w} / \mathrm{v}, 100 \mu \mathrm{L}\right.$ per well) at $37^{\circ} \mathrm{C}$ for $1 \mathrm{~h}$. After washing, the wells were filled with $100 \mu \mathrm{L}$ of serial dilutions of ConA-HRP or WGA-HRP $\left[100 \mu \mathrm{L}\right.$, from $10^{-1}$ to $10^{-7} \mathrm{mg} \mathrm{mL}^{-1}$ in PBS ( $\mathrm{pH} 7.4$ ) or PBS containing $0.1 \mathrm{mM} \mathrm{Ca}^{2+}$, $0.1 \mathrm{mM} \mathrm{Mn}^{2+}$ (for ConA) and BSA $\left.(0.3 \% \mathrm{w} / \mathrm{v})\right]$ and were incubated at $37^{\circ} \mathrm{C}$ for $1 \mathrm{~h}$. The plates were washed with T-PBS $(3 \times 100 \mu \mathrm{L}$ per well), then the colour was developed using OPD $(100 \mu \mathrm{L}$ per well, $0.4 \mathrm{mg} \mathrm{mL}^{-1}$ in $0.05 \mathrm{M}$ phosphate-citrate buffer) and urea hydrogen peroxide $\left(0.4 \mathrm{mg} \mathrm{mL}^{-1}\right)$. The reaction was stopped after $10 \mathrm{~min}$ by adding $\mathrm{H}_{2} \mathrm{SO}_{4}(30 \% \mathrm{v} / \mathrm{v}, 50 \mu \mathrm{L}$ per well), and the absorbance was measured at $490 \mathrm{~nm}$. The concentration of ConA- 
HRP or WGA-HRP that gave an absorbance of between 0.8 and 1 was used for inhibition experiments.

Inhibition Experiments: The microtitre plates were coated with $\alpha$ D-Man-PAA or D-GlcNAc-PAA as described previously. Serial two-fold dilutions of each inhibitor were incubated for $1 \mathrm{~h}$ at $37{ }^{\circ} \mathrm{C}$ in PBS on Nunclon (Delta) microtitre plates $(60 \mu \mathrm{L}$ per well) in the presence of ConA-HRP or WGA-HRP $(60 \mu \mathrm{L})$ at the desired concentration. The above solutions $(100 \mu \mathrm{L})$ were then transferred to the coated microtitre plates, which were then incubated for $1 \mathrm{~h}$ at $37^{\circ} \mathrm{C}$. After incubation, the plates were washed with T-PBS, and the colour was revealed as described above. The percentage of inhibition was plotted against the logarithm of the concentration of the sugar derivatives. The sigmoidal curves were fitted, and the concentration at $50 \%$ inhibition of binding of the ConA-HRP to $\alpha$ D-Man-PAA or WGA-HRP to D-GlcNAc-PAA coated plates were determined $\left(\mathrm{IC}_{50}\right)$. The percentages of inhibition were calculated as given in the equation below, where $A=$ absorbance

$\%$ inhibition $=\left(A_{\text {(no inhibitor) }}-A_{\text {(with inhibitor) }}\right) / A_{\text {(no inhibitor) }} \times 100$

Supporting Information (see footnote on the first page of this article): ${ }^{1} \mathrm{H}$ and ${ }^{13} \mathrm{C}$ NMR spectra of new compounds.

\section{Acknowledgments}

The authors thank the University of Ferrara, the University Joseph Fourier (UJF), the Centre National de la Recherche Scientifique (CNRS), and the "Communauté d'agglomération Grenoble-Alpes Métropole" (Nanobio program) for financial support, Dr. A. Cavazzini and Dr. E. Bianchini (University of Ferrara) for performing the elemental analyses, and Dr. M. Fiore (UJF) for the stability assays on the POSS-based glycoclusters.

[1] For reviews, see: a) R. H. Baney, M. Itoh, A. Sakakibara, T. Suzuki, Chem. Rev. 1995, 95, 1409-1430; b) D. B. Cordes, P. D. Lickiss, F. Rataboul, Chem. Rev. 2010, 110, 2081-2173.

[2] D. Heyl, E. Rikowski, R. C. Hoffmann, J. J. Schneider, W.-D. Fessner, Chem. Eur. J. 2010, 16, 5544-5546.

[3] B. Trastoy, M. E. Pérez-Ojeda, R. Sastre, J. L. Chiara, Chem. Eur. J. 2010, 16, 3833-3841.

[4] M. Lo Conte, S. Staderini, A. Chambery, N. Berthet, P. Dumy, O. Renaudet, A. Marra, A. Dondoni, Org. Biomol. Chem. 2012, 10, 3269-3277.

[5] a) Y. C. Lee, R. T. Lee, Acc. Chem. Res. 1995, 28, 321-327; b) J. J. Lundquist, E. J. Toone, Chem. Rev. 2002, 102, 555-578.

[6] A POSS derivative bearing eight $p$-ethynylphenyl groups connected to the core through a triazole linker has been recently described, see: S. Fabritz, D. Heyl, V. Bagutski, M. Empting,
E. Rikowski, H. Frauendorf, I. Balog, W.-D. Fessner, J. J. Schneider, O. Avrutina, H. Kolmar, Org. Biomol. Chem. 2010, 8, 2212-2218

[7] A. B. Lowe, C. E. Hoyle, C. N. Bowman, J. Mater. Chem. 2010, $20,4745-4750$

[8] a) A. Dondoni, Angew. Chem. 2008, 120, 9133-9135; Angew. Chem. Int. Ed. 2008, 47, 8995-8997; b) C. E. Hoyle, C. N. Bowman, Angew. Chem. 2010, 122, 1584-1617; Angew. Chem. Int. Ed. 2010, 49, 1540-1573; c) A. Dondoni, A. Marra, Chem. Soc. Rev. 2012, 41, 573-586.

[9] R. Hoogenboom, Angew. Chem. 2010, 122, 3489-3491; Angew. Chem. Int. Ed. 2010, 49, 3415-3417.

[10] a) J. W. Chan, H. Zhou, C. E. Hoyle, A. B. Lowe, Chem. Mater 2009, 21, 1579-1585; b) D. Konkolewicz, A. G. Weale, E. Perrier, J. Am. Chem. Soc. 2009, 131, 18075-18077.

[11] a) M. Lo Conte, S. Pacifico, A. Chambery, A. Marra, A. Dondoni, J. Org. Chem. 2010, 75, 4644 4647; b) M. Minozzi, A. Monesi, D. Nanni, P. Spagnolo, N. Marchetti, A. Massi, J. Org. Chem. 2011, 76, 450-459; c) C. Wang, P.-F. Ren, X.-J. Huang, J. Wu, Z.-K. Xu, Chem. Commun. 2011, 47, 3930-3932; d) Y. Huang, Y. Zeng, J. Yang, Z. Zeng, F. Zhu, X. Chen, Chem. Commun. 2011, 47, 7509-7511; e) M. Lo Conte, S. Staderini, A. Marra, M. Sanchez-Navarro, B. G. Davis, A. Dondoni, Chem. Commun. 2011, 47, 11086-11088.

[12] M. Meldal, C. W. Tornøe, Chem. Rev. 2008, 108, 2952-3015.

[13] a) H. Lang, C. Duschl, H. Vogel, Langmuir 1994, 10, 197-210; b) G. H. Woehrle, M. G. Warner, J. E. Hutchison, Langmuir 2004, 20, 5982-5988.

[14] N. Floyd, B. Vijayakrishnan, J. R. Koeppe, B. G. Davis, Angew. Chem. 2009, 121, 7938-7942; Angew. Chem. Int. Ed. 2009, 48, 7798-7802.

[15] In previous work (see ref. ${ }^{[11 \mathrm{a}, 11 \mathrm{e}]}$ ) in which the formation of the vinyl thioether intermediate was monitored by ${ }^{1} \mathrm{H}$ NMR spectroscopy and then trapped by a thiol in a TEC reaction, the presence of the alkene protons was revealed by their resonances at $\delta=5.5-6.5 \mathrm{ppm}$.

[16] B. Trastoy, D. A. Bonsor, M. E. Pérez-Ojeda, M. L. Jimeno, A. Méndez-Ardoy, J. M. Garcia Fernández, E. J. Sundberg, J. L. Chiara, Adv. Funct. Mater. 2012, 22, 3191-3201.

[17] M. Sleiman, A. Varrot, J.-M. Raimundo, M. Gingras, P. G. Goekjian, Chem. Commun. 2008, 6507-6509.

[18] J. E. Gestwicki, C. W. Cairo, L. E. Strong, K. A. Oetjen, L. L. Kiessling, J. Am. Chem. Soc. 2002, 124, 14922-14933.

[19] M. Gomez-Garcia, J. M. Benito, R. Gutierrez-Gallego, A. Maestre, C. Ortiz Mellet, J. M. Garcia Fernandez, J. L Jiménez Blanco, Org. Biomol. Chem. 2010, 8, 1849-1860.

[20] Y. M. Chabre, R. Roy, Adv. Carbohydr. Chem. Biochem. 2010, 63, 165-393.

[21] D. Deniaud, K. Julienne, S. G. Gouin, Org. Biomol. Chem. 2011, 9, 966-979.

Received: October 30, 2012

Published Online: January 14, 2013 